\title{
THE CONCENTRATION OF AUREOMYCIN IN URINE AND CERE- BROSPINAL, PLEURAL AND ASCITIC FLUIDS AFTER ORAL AND INTRAVENOUS ADMINISTRATION ${ }^{1}$
}

\author{
BY HARRY F. DOWLING, MARK H. LEPPER, ESTON R. CALDWELL, JR., \\ RICHARD L. WHELTON, AND ROBERT L. BRICKHOUSE \\ (From the George Washington University Medical Division, Gallinger Municipal Hospital, \\ and the Department of Medicine, George Washington University, Washington, D. C.)
}

During our previously reported studies (1) on the absorption of aureomycin in humans after oral and intramuscular administration, we found that aureomycin was sometimes present in the cerebrospinal fluid. We have extended these studies in order to determine the conditions under which aureomycin will be detectable. The present paper includes the cerebrospinal fluid findings in 26 subjects with no inflammation of the central nervous system and in one patient with meningitis and two with encephalitis together with a small number of tests for aureomycin concentration in urine and in pleural and ascitic fluids.

\section{METHOD}

Cerebrospinal fluid specimens were obtained simultaneously with specimens of serum on two patients after a single dose of $2 \mathrm{gm}$. by mouth, on four after a single $1 \mathrm{gm}$. dose, and on 18 patients who were under treatment with aureomycin ${ }^{2}$ in doses of 250 to $500 \mathrm{mg}$. every three hours by mouth. Five subjects were given a single intravenous dose of $500 \mathrm{mg}$. of aureomycin and a single specimen of blood and spinal fluid was taken three or four hours later. One patient with a pleural effusion was given oral aureomycin and simultaneous blood and pleural fluid specimens were obtained. The same procedure was followed in the case of a patient with cirrhosis and ascites.

Aureomycin concentrations were determined by a modification of Dornbush's (2) method, as previously described by us (1).

\section{RESULTS}

Distribution into the Cerebrospinal Fluid. As shown in Figure 1, aureomycin was present in the cerebrospinal fluid in only one among 17 specimens obtained within the first 12 hours of aureomycin therapy. Five patients were given a single

\footnotetext{
1 Presented at the Second National Symposium on Recent Advances in Antibiotics Research held in Washington, D. C., April 11-12, 1949, under the auspices of the Antibiotics Study Section, National Institutes of Health, Public Health Service, Federal Security Agency.

2 Supplied by the Lederle Laboratories Division, American Cyanamid Co.
}

intravenous dose of $500 \mathrm{mg}$. of aureomycin in 25 cc. of arginine or leucine buffer solution. Three to four hours later the serum aureomycin concentration was $2 \mu \mathrm{g}$. in each instance. At the same time $0.06 \mu \mathrm{g}$. was present in the cerebrospinal fluid of one patient and $0.03 \mu \mathrm{g}$. in the fluid of two patients, while detectable amounts of aureomycin were not demonstrated in the cerebrospinal fluids of the two remaining patients.

All of the 16 specimens of cerebrospinal fluid obtained from patients who had received the antibiotic for 23 hours or more contained demonstrable concentrations of aureomycin. The presence of meningitis apparently made no difference in the cerebrospinal fluid concentration attained. Two specimens obtained from patients with encephalitis contained unusually high cerebrospinal fluid concentrations compared with serum concentrations. In general, the higher the serum concentration the higher the concentration in the cerebrospinal fluid. There was no indication that after the first 24 hours there was any further rise in the spinal fluid concentration unless the dose of aureomycin was increased sufficiently to cause a rise in the serum concentration.

Distribution in Pleural and Ascitic Fluids. One patient with a pleural effusion had a concentration of aureomycin in the serum of $0.5 \mu \mathrm{g} . / \mathrm{cc}$. and 0.125 $\mu \mathrm{g} . / \mathrm{cc}$. in the pleural fluid (Table I). Another patient with cirrhosis and ascites had concentrations of aureomycin in the ascitic fluid of 0.125 and $1.0 \mu \mathrm{g}$. at the same time that serum concentrations were 0.5 and $1 \mu \mathrm{g}$. , respectively. A third concentration of $0.03 \mu \mathrm{g}$. was obtained at a time when a simultaneous serum level was not done.

Excretion in the Urine. The amount of aureomycin excreted in the urine after oral and intravenous administration is shown in Table II. One patient was given a single dose of $1 \mathrm{gm}$. and another $700 \mathrm{mg}$. by mouth. The concentration of the antibiotic in the urine was 64 to $128 \mu \mathrm{g} . / \mathrm{cc}$. in 
TABLE I

Distribution of aureomycin in pleural and ascitic fluids

\begin{tabular}{l|l|c|c|c}
\hline \hline Patient & Diagnosis & $\begin{array}{c}\text { Day } \\
\text { of } \\
\text { treat- } \\
\text { ment* }\end{array}$ & $\begin{array}{l}\text { Concentration of } \\
\text { aureomycin } \\
\mu \text { \&l./cc. }\end{array}$ \\
\cline { 3 - 5 } & & & Serum & $\begin{array}{l}\text { Serous } \\
\text { cavity } \\
\text { fluid }\end{array}$ \\
\hline L. C. & $\begin{array}{l}\text { Pleural effusion (probably } \\
\text { tuberculosis) }\end{array}$ & 2 & 0.5 & 0.125 \\
E. Q. & $\begin{array}{l}\text { Cirrhosis with ascites } \\
2\end{array}$ & $\begin{array}{l}0.5 \\
\text { ND }\end{array}$ & $\begin{array}{l}0.125 \\
0.03 \\
1.0\end{array}$ \\
\hline
\end{tabular}

*With $250 \mathrm{mg}$. of aureomycin every three hours

both instances and the urinary output during six hours was 1095 and 1060 cc., respectively. The percentage of the dose recovered in the first six hours was 11 and 15.4 per cent, respectively.

Five patients were given a single intravenous dose of $300 \mathrm{mg}$. One patient (J. M.) had low concentrations in the blood and in the urine and also a lower urine volume than the two patients described above. In the first six hours he excreted only 4 per cent of the dose administered. The other four patients had higher serum and urine concentrations. One of these excreted 2 per cent in two hours and the other three excreted 5, 2.3, and 3.7 per cent, respectively, in one hour.

The most interesting finding was the relationship between the serum and the urine concentrations, which was remarkably constant considering the crudeness of the biological test employed. The ratio of serum concentration to urine concentration varied from $1: 48$ to $1: 400$ but was usually in the neighborhood of $1: 100$. This was true even in the case of C. F. who, although he was given 500 $\mathrm{mg}$. intravenously, voided only $60 \mathrm{cc}$. of urine two hours and again four and one-half hours after the injection, and who was later found to have urinary retention. He had a serum concentration of $2 \mu \mathrm{g} . / \mathrm{cc}$. and urine concentrations of 200 and $100 \mu \mathrm{g} . / \mathrm{cc} .$, a ratio of $1: 100$ and $1: 50$.

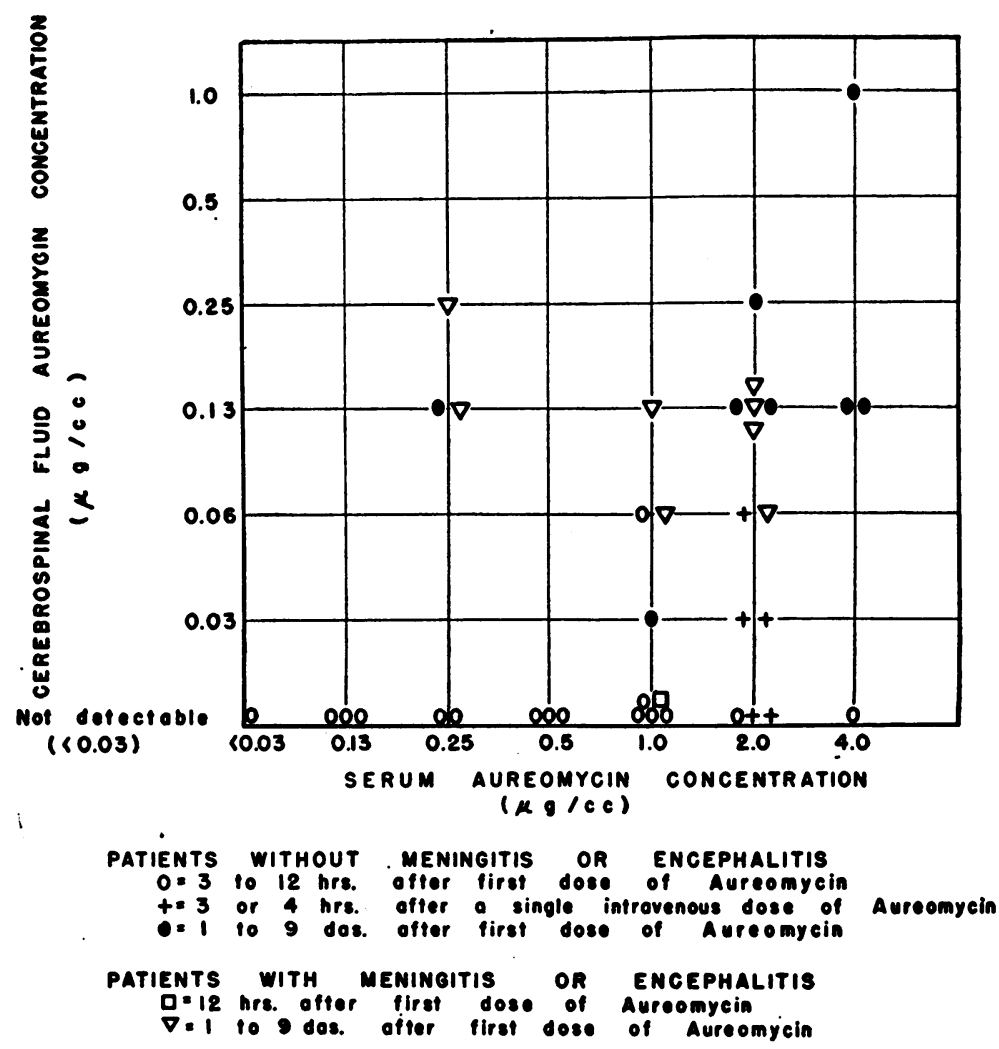

Fig. 1. The Concentration of Aureomycin in Urine and Cerebrospinal, Pleural and Ascitic Fluids After Oral and Intravenous Administration 
TABLE II

Concentrations of aureomycin in urine and serum after oral and intravenous administration

\begin{tabular}{|c|c|c|c|c|c|c|c|c|c|}
\hline \multirow{3}{*}{ Patient } & \multirow{3}{*}{$\begin{array}{l}\text { Dose } \\
\text { and } \\
\text { route }\end{array}$} & \multicolumn{6}{|c|}{ Urine } & \multirow{3}{*}{$\begin{array}{l}\text { Serum } \\
\text { concen- } \\
\text { tration }\end{array}$} & \multirow{3}{*}{$\underset{\text { Urine }}{\text { Serum/ }}$} \\
\hline & & \multirow{2}{*}{$\begin{array}{c}\text { Hour } \\
\text { collected }\end{array}$} & \multirow{2}{*}{ Volume } & \multirow{2}{*}{$\begin{array}{l}\text { Concen- } \\
\text { tration }\end{array}$} & \multirow{2}{*}{ Recovered } & \multicolumn{2}{|c|}{ Per cent recovered } & & \\
\hline & & & & & & $\begin{array}{l}\text { In time } \\
\text { period }\end{array}$ & Cumulative & & \\
\hline E. P. & 1 gm. P.O. & $\begin{array}{l}0-2 \\
2-4 \\
4-6 \\
\text { Total }\end{array}$ & $\begin{array}{c}c c . \\
470 \\
500 \\
125 \\
1095\end{array}$ & $\begin{array}{c}\mu g . / c c . \\
64 \\
128 \\
128\end{array}$ & $\begin{array}{l}m g . \\
30 \\
64 \\
16\end{array}$ & $\begin{array}{l}3.0 \\
6.4 \\
1.6\end{array}$ & $\begin{array}{r}3.0 \\
9.4 \\
11.0\end{array}$ & $\begin{array}{l}\mu g . / c c . \\
1.0\end{array}$ & $\overline{\overline{1}} \overline{128}$ \\
\hline N. B. & 700 mg. P.O. & $\begin{array}{c}0-2 \\
2-4 \\
4-6 \\
\text { Total }\end{array}$ & $\begin{array}{r}435 \\
475 \\
150 \\
1060\end{array}$ & $\begin{array}{r}64 \\
128 \\
128\end{array}$ & $\begin{array}{l}28 \\
61 \\
19\end{array}$ & $\begin{array}{l}4.0 \\
8.7 \\
2.7\end{array}$ & $\begin{array}{r}4.0 \\
12.7 \\
15.4\end{array}$ & $\begin{array}{l}0.25 \\
1.0\end{array}$ & $\begin{array}{c}1: 256 \\
1: 128 \\
-\end{array}$ \\
\hline J. M. & $300 \mathrm{mg} . \mathrm{I} . \mathrm{V}$. & $\begin{array}{l}0-2 \\
2-4 \\
4-6 \\
\text { Total }\end{array}$ & $\begin{array}{l}175 \\
160 \\
265 \\
600\end{array}$ & $\begin{array}{l}12.5 \\
50 \\
6\end{array}$ & $\begin{array}{l}2 \\
8 \\
2\end{array}$ & $\begin{array}{l}0.7 \\
2.7 \\
0.7\end{array}$ & $\begin{array}{l}0.7 \\
3.3 \\
4.0\end{array}$ & $\begin{array}{l}0.25 \\
0.125 \\
0.125\end{array}$ & $\begin{array}{l}1: 50 \\
1: 400 \\
1: 48\end{array}$ \\
\hline J. C. & $300 \mathrm{mg} . \mathrm{I} . \mathrm{V}$. & $0-2$ & 60 & 100 & 6 & 2.0 & - & 1.0 & $1: 100$ \\
\hline W. B. & $300 \mathrm{mg} . \mathrm{I} . \mathrm{V}$. & $0-1$ & 150 & 100 & 15 & 5.0 & 一 & 1.0 & $1: 100$ \\
\hline W. L. & $300 \mathrm{mg} . \mathrm{I} . \mathrm{V}$. & $0-1$ & 65 & 100 & 7 & 2.3 & 一 & 1.0 & $1: 100$ \\
\hline J. B. & $300 \mathrm{mg} . \mathrm{I} . \mathrm{V}$. & $0-1$ & 215 & 50 & 11 & 3.7 & 一 & 0.25 & $1: 200$ \\
\hline C. F.* & $500 \mathrm{mg} . \mathrm{I} . \mathrm{V}$. & $\begin{array}{l}0-2 \\
2-4 \frac{1}{2}\end{array}$ & $\begin{array}{l}60 \\
60\end{array}$ & $\begin{array}{l}200 \\
100\end{array}$ & $\begin{array}{l}1 \\
1\end{array}$ & $\begin{array}{l}0.2 \\
0.2\end{array}$ & $\begin{array}{l}0.2 \\
0.4\end{array}$ & $\begin{array}{l}2.0 \\
2.0\end{array}$ & $\begin{array}{l}1: 100 \\
1: 50\end{array}$ \\
\hline
\end{tabular}

* Had prostatic hypertrophy and urinary retention.

\section{DISCUSSION}

It is apparent that after the first 24 hours of therapy with the doses of aureomycin in common use, detectable levels of the antibiotic are consistently present in the cerebrospinal fluid. Larger doses, producing higher serum concentrations, should result in higher cerebrospinal fluid levels. In some instances the antibiotic is present three hours after an intravenous injection of $500 \mathrm{mg}$. It is likely that higher intravenous doses might assure the presence of the antibiotic in the spinal fluid in all cases within a few hours. It is of interest that the one patient with pneumococcic meningitis whom we treated with oral doses of aureomycin recovered. The concentration of aureomycin in his cerebrospinal fluid was not detectable 12 hours after the start of therapy, but was 0.06 to $0.13 \mu \mathrm{g}$. thereafter. This patient received two doses of sulfonamides before aureomy- cin was started. These may have prevented the progression of the meningitis before aureomycin was available at the site of the infection, although we doubt that they could have been responsible for the patient's recovery. In this connection, it is of interest that we have found the sensitivity of 26 strains of pneumococci to range between 0.01 and $0.16 \mu \mathrm{g}$. of aureomycin. Seventeen of the strains were sensitive to $0.02 \mu \mathrm{g}$. or less. Our preliminary studies show that aureomycin can be transmitted into the pleural and ascitic fluids when it is administered systemically. Whether this is true in all cases and whether the concentrations are sufficient for therapeutic effects are problems which await further study. The large volumes of urine obtained in some cases, and our observations on a number of patients under treatment with aureomycin, lead us to believe that aureomycin has a diuretic effect. The amount excreted is closely related to the serum concentration, the ratio of 
serum concentration to urine concentration being in the neighborhood of $1: 100$. This makes it likely that aureomycin is excreted as a glomerular filtrate. From our previous studies (1), which indicate that the serum concentrations are very low after 12 hours, and the fact that there is a constant serum-urine ratio, it can be deduced that the major portion of the aureomycin recoverable in the urine is excreted within 12 hours and that only relatively small amounts are recoverable thereafter. It would appear, therefore, that at most, only 15 to 20 per cent of the antibiotic will be recovered in the urine even after intravenous administration. Collins and his associates (3), measuring complete aureomycin excretion in two patients, found that 11 to 13 per cent was recovered after oral administration. The data available at present indicate, therefore, that the major portion of an intravenous dose of aureomycin is disposed of by methods other than urinary excretion and that the percentage recoverable in the urine is so small that the figure is of relatively little value in estimating the completeness of absorption from the gastro-intestinal tract.

\section{SUMMARY}

1. Among 17 specimens of cerebrospinal fluid obtained during the first 12 hours of oral administration, aureomycin was detectable in only one. When five patients were given an intravenous dose of $500 \mathrm{mg}$., detectable concentrations were present in the cerebrospinal fluids of three patients within four hours. Aureomycin was present in all 16 specimens obtained 23 or more hours after the first oral dose, the concentrations ranging from 0.03 to $1 \mu \mathrm{g}$. and being approximately related to the serum concentration present at the same time.

2. Aureomycin has been found in the pleural and ascitic fluids of two patients after oral administration.

3. Urine studies on eight patients showed an aureomycin concentration of 12.5 to $100 \mu \mathrm{g}$./cc. during the first hour after oral or intravenous administration, depending upon the height of the serum concentration and the volume of urine excreted. The ratio of the aureomycin concentrations of serum to urine was approximately $1: 100$.

\section{ACK NOWLEDGMENT}

We wish to thank Mrs. Joan R. Broyhill, Miss Pearl Roberts and Miss Myrtle I. Meyer for technical assistance.

\section{BIBLIOGRAPHY}

1. Lepper, M. H., Dowling, H. F., Brickhouse, R. L., and Caldwell, E. R., Jr., Blood and cerebrospinal fluid concentrations of aureomycin after oral and intramuscular administration. J. Lab. \& Clin. Med., 1949, 34, 366.

2. Dornbush, A. C., and Pelcak, E. J., The determination of aureomycin in serum and other body fluids. Ann. New York Acad. Sc., 1948, 51, 218.

3. Collins, H. S., Wells, E. B., Paine, T. F., Jr., and Finland, M., Urinary excretion of aureomycin. Proc. Soc. Exper. Biol. \& Med., 1948, 69, 174. 